\title{
Genotypic characterization of HIV-1 C variants in PBMCs and cervicovaginal cells
}

\author{
Varsha M Prabhu, Varsha S Padwal, Shilpa M Velha, Atmaram H Bandivdekar \\ From 2nd International Science Symposium on HIV and Infectious Diseases (HIV SCIENCE 2014) \\ Chennai, India. 30 January - 1 February 2014
}

\section{Background}

HIV-1 is primarily a mucosal pathogen since more than $80 \%$ of infections occur through genital exposure. Vaginal intercourse, though an inefficient mode of transmission, contributes more new infections worldwide than any other route. Also, the female reproductive tract has been identified as a compartment that harbors variants distinct from blood. Present study aims to highlight viral compartmentalization between these compartments reflecting inadequate ART penetration.

\section{Methods}

In this study blood and cervicovaginal swabs were collected from 8 female subjects. CD4 counts and viral loads were determined. Translated amino acid sequences of $\mathrm{C} 2 \mathrm{v} 3$ region of env gene of proviral HIV-1 C in PBMCs and genital cells were analyzed using N-Glycosite and Geno2pheno [Co receptor] 1.2 programs for presence of $\mathrm{N}$ linked glycosylation sites and co receptor preference, respectively.

\section{Results}

Characterization of translated amino acid sequences of C2 v3 region of env gene of HIV-1 C shows variation in the number of $\mathrm{N}$ linked glycosylation (NLG) sites and uniform co receptor preference. Viral load varies in blood and genital secretions.

\section{Conclusion}

Genotypic characterization of viral variants in blood and female reproductive tract can provide information regarding their association with sexual transmission of HIV. Difference in the number of NLG sites observed may influence the affinity for host cell co receptor. Discrepancies in viral load of blood and genital secretions suggest that ART

\footnotetext{
* Correspondence: batmaram@gmail.com

Department of Biochemistry, National Institute for Research in Reproductive Health, Mumbai, India
}

Submit your next manuscript to BioMed Central and take full advantage of:

- Convenient online submission

- Thorough peer review

- No space constraints or color figure charges

- Immediate publication on acceptance

- Inclusion in PubMed, CAS, Scopus and Google Scholar

- Research which is freely available for redistribution 